\title{
Effect of Coronatine on the Decomposition of Starch Grains in the Dises of Potato Tuber
}

\author{
Ryutaro SAKAI*, Yôsuke Mino*, Masako TAKACHI* and Sawako ENOKI* \\ 酒井隆太郎*・美濃羊輔 $*$ 高地雅子*・榎佐和子* : ジャガイモ塊茎 \\ 切片中の測粉粒分解におよぼすコロナチンの影響
}

\begin{abstract}
Effect of coronatine an extracellular toxin produced by Pseudomonas coronafaciens var. atropurpurea, on the decomposition of starch grains was examined using the tuber discs of potato (Solanum tuberosum L. cv. Shiretoko). Small-sized starch grains (below $30 \mu \mathrm{m}$ in diameter) were preferentially decomposed by coronatine treatment, accompanied by increasing cell size. Similarity was also found between coronatine and the bacterium treatment. Amylase activity increased considerably in the discs treated with coronatine, but phosphorylase and debranching enzyme activities kept almost unchanged. The swelling of the cell brought about by coronatine may be attributed to the increase in osmotic pressure resulted from starch decomposition, together with the loosening of the cell wall.
\end{abstract}

(Received August 2, 1979)

\section{Introduction}

Coronatine ${ }^{2)}$ is an extracellular toxin produced by Pseudomonas coronafaciens var. atropurpurea (Reddy and Godkin) Stapp and induces the necrosis with chlorotic halo symptoms on Italian ryegrass (Lolium multiflorum LAM.) ${ }^{6}$. This compound also induces marked hypertrophy on potato tuber tissues, accompanied by the loosening of cell walls ${ }^{7}$ and disappearance of starch grains in the cells. Elucidation of the physiological actions of coronatine is considered to be important to clarify the mechanism of pathogenicity of this disease. The present work was attempted to investigate the disappearance of starch grains from the enzymological viewpoints.

\section{Materials and Methods}

Plant material. The tubers of potato (Solanum tuberosum L. cv. Shiretoko) cultivated at Konsen Agricultural Experiment Station in 1978 were used throughout this study. The cylinders $(2 \mathrm{~cm}$ in diameter) were prepared by punching out tuber tissues with a cork borer and then cut into discs ( $2 \mathrm{~mm}$ in thickness) with a razor. After the discs were washed for $30 \mathrm{~min}$ in running tap water, the excess water on the surfaces was sucked up with a filter paper.

Coronatine or the bacterium treatment. Fifty microliters of $20 \%$ acetone solution containing $0.1 \mathrm{mM}$ coronatine were applied on one side of a disc. A control

* Obihiro University of Agriculture and Veterinary Medicine, Hokkaido 080, Japan

帯広畜産大学環境植物学研究室 
disc was also treated with $20 \%$ acetone solution. Three coronatine-treated and nontreated discs, respectively, were put on a moistened filter paper in a Petri dish $(9 \mathrm{~cm}$ in diameter) and incubated at $22 \mathrm{C}$ in a thermostat.

$P$. coronafaciens var. atropurpurea was cultured on a potato extract agar slant at $23 \mathrm{C}$ for 2 days. The cultured bacterium was collected and washed with phosphate buffer $(\mathrm{M} / 15, \mathrm{pH} 6.8)$, followed by suspending in sterile distilled water. Fifty microliters of the bacterial suspension (concentration $1.0 \mathrm{OD}_{500}$ ) were applied to a disc as was the case for coronatine treatment.

Microscopy. The slices of a disc cut longitudinally with a razor were stained with neutral red for the observation under a light microscope.

Enzyme preparation. As shown in Table 1, amylase activity was considera-

Table 1. Inactivation of amylase activity in the homogenate solution of potato tuber discs in the browning process

\begin{tabular}{c|c|c}
\hline $\begin{array}{l}\text { Time after } \\
\text { homogenization }\end{array}$ & $\begin{array}{l}\text { Degree of } \\
\text { browning }\end{array}$ & Amylase activity \\
\hline $0(\min )$ & 0.30 & 702 \\
30 & 0.39 & 661 \\
60 & 0.59 & 512 \\
\hline
\end{tabular}

The degree of browning is expressed as the absorbance at $450 \mathrm{~nm}$ and amylase activity as the amount of starch decom$\operatorname{posed}(\mu \mathrm{g} / \mathrm{ml})$. bly inactivated in the processes of the oxidation of phenolics by polyphenol oxidase. The following homogenizing solution was therefore used to protect amylase from the oxidation products. The discs were homogenized in $10 \mathrm{ml}$ of phosphate buffer (M/15, pH 6.8) containing $0.1 \mathrm{M}$ sodium ascorbate, 10 $\mathrm{mM}$ L-cysteine and $10 \mathrm{mM}$

sodium diethyldithiocarbamate for $5 \mathrm{~min}$ in a chilled mortar with a pestle. The homogenate was centrifuged at $12,000 \times \mathrm{g}$ for $10 \mathrm{~min}$. To the supernatant was added solid ammonium sulfate up to $70 \%$ saturation. The precipitate was collected by centrifugation at $12,000 \times g$ for $10 \mathrm{~min}$ after standing for $30 \mathrm{~min}$ at room temperature and then dissolved in $3 \mathrm{ml}$ of $0.1 \mathrm{M} \mathrm{NaCl}$ solution. This crude enzyme solution was chromatographed on Sephadex G-25 column $(2.2 \mathrm{~cm} \times 20 \mathrm{~cm})$ to separate proteins from the low molecular substances added. The elution was carried out at the flow rate of $60 \mathrm{ml} / \mathrm{hr}$ using the same $\mathrm{NaCl}$ solution. The eluate was collected in $5-\mathrm{ml}$ fractions. The fractions of tube Nos. 7 and 8 were combined and diluted up to 15 $\mathrm{ml}$ by the addition of distilled water for the test of starch degrading activities.

\section{Assays of enzyme activities.}

Amylase activity. The reaction mixture consisted of $2 \mathrm{ml}$ of each enzyme solution and acetate buffer $(0.5 \mathrm{M}, \mathrm{pH} 6.5)$ containing $0.5 \%$ soluble starch. Incubated at $30 \mathrm{C}$ for $3 \mathrm{hr}$, the reaction mixture was promptly neutralized to $\mathrm{pH} 7.0$ with 0.1 $\mathrm{N} \mathrm{NaOH}$ solution. Zinc sulfate and barium hydroxide solutions of $0.25 \mathrm{ml}$ each were added successively to the mixture to remove proteins. After centrifugation at $12,000 \times g$ for $5 \mathrm{~min}$, the reducing sugars contained in the supernatant was determined by the method of Somogyi-Nelson ${ }^{1)}$ using a spectrophotometer (Shimazu UV 140). The amylase activity was expressed as the amount of reducing sugars produced $(\mu \mathrm{g})$ for $3 \mathrm{hr}$ by one $\mathrm{ml}$ of the enzyme solution.

Phosphorylase activity. The reaction mixture consisted of $0.5 \mathrm{ml}$ of enzyme solution, $0.5 \mathrm{ml}$ of $0.1 \mathrm{M}$ glucose-1-phosphate and $0.55 \mathrm{ml}$ of $15 \mathrm{mM}$ ammonium molybdate (as an inhibitor for phosphatase). After incubation at $30 \mathrm{C}$ for $30 \mathrm{~min}$, $0.2 \mathrm{ml}$ of the mixture were pipetted out to be reacted with $3.8 \mathrm{ml}$ of an iodine reagent ${ }^{9)}$. The blue color developed was measured using the spectrophotometer. The phosphorylase activity was expressed as the amount of starch synthesized(mg) 
for $10 \mathrm{~min}$ by one $\mathrm{ml}$ of the enzyme solution.

Debranching enzyme. The reaction mixture consisted of $2 \mathrm{ml}$ of each enzyme solution and acetate buffer $(0.5 \mathrm{M}, \mathrm{pH} 6.5)$ containing $1 \%$ pullulan. The reaction condition and determination of reducing sugars were the same as those for amylase assay. The enzyme activity was expressed as the amount of reducing sugars produced $(\mu \mathrm{g})$ for $3 \mathrm{hr}$ by one $\mathrm{ml}$ of the enzyme solution.

Determination of reducing sugars in the discs. Ten discs were homogenized in $15 \mathrm{ml}$ of $80 \%$ ethanol solution in a mortar with a pestle, followed by centrifugation at $12,000 \times \mathrm{g}$ for $5 \mathrm{~min}$. The supernatant was increased up to $25 \mathrm{ml}$ by the addition of the same ethanol solution and then diluted to $250 \mathrm{ml}$ with distilled water for determining the amount of reducing sugars by the method described above ${ }^{1)}$.

Inhibition of amylase activity by $\mathrm{HgCl}_{2}$ or heat treatment. The enzyme solution prepared from the discs treated with coronatine for $24 \mathrm{hr}$. The enzyme solution at different concentrations of $\mathrm{HgCl}_{2}$ were prepared by dissolving given amount of $\mathrm{HgCl}_{2}$ into the buffer solution. The enzyme solution was heated in the presence of $0.1 \mathrm{mM} \mathrm{CaCl}_{2}$ at a designed temperature for $3 \mathrm{~min}$ in a water bath and then cooled promptly in running tap water. The reaction mixture and condition were the same as described previously.

\section{Results}

\section{Decomposition of starch grains}

The results in Fig. 1 and 2 indicate that starch grains in the discs treated with
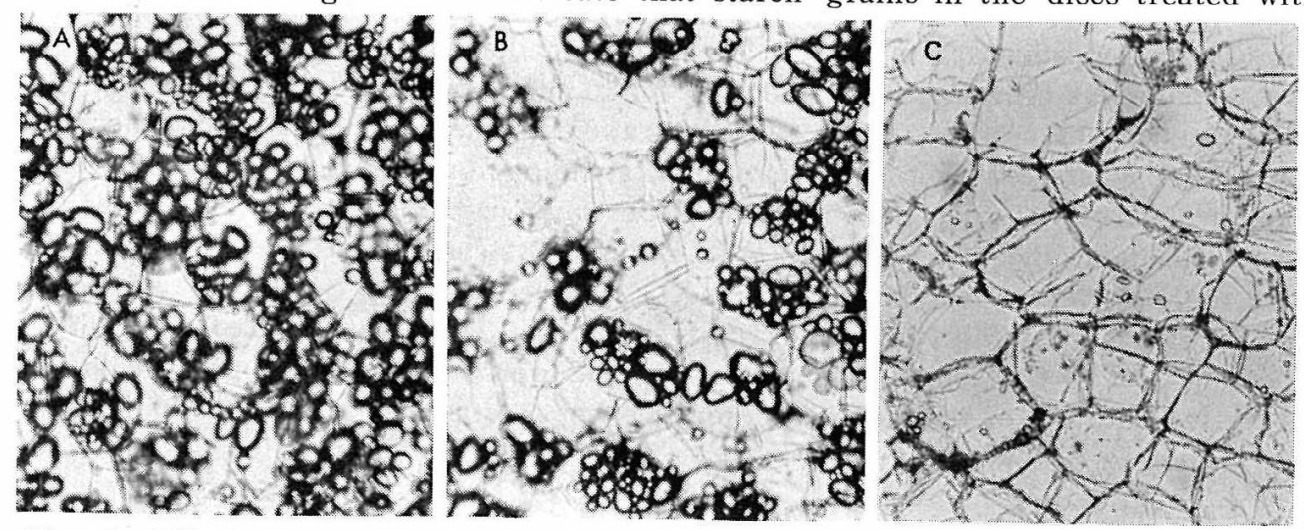

Plate 1. Effect of coronatine treatments on the variations in the number of starch grains and cell size. A, B and C indicate control, 3 days after treatment and 5 days after treatment, respectively.

coronatine were rapidly decomposed in parallel with increasing cell size as was illustrated in Plate 1, but not in non-treated discs. Similarity was also found between treatment with coronatine and the bacterium. On the other hand, the number of large-sized starch grains (above $30 \mu \mathrm{m}$ ) per cell kept almost unchanged during the period examined irrespective of the kinds of treatment, suggesting that small-sized ones were preferentially decomposed by treatment with coronatine (Fig. 3 ).

\section{Variations in the enzyme activities}

As shown in Fig. 4, amylase activity increased considerably in the discs treated with coronatine within $24 \mathrm{hr}$, but did not in the case of non-treated discs. The amylase activity decreased below their initial levels, respectively, in the treated and 


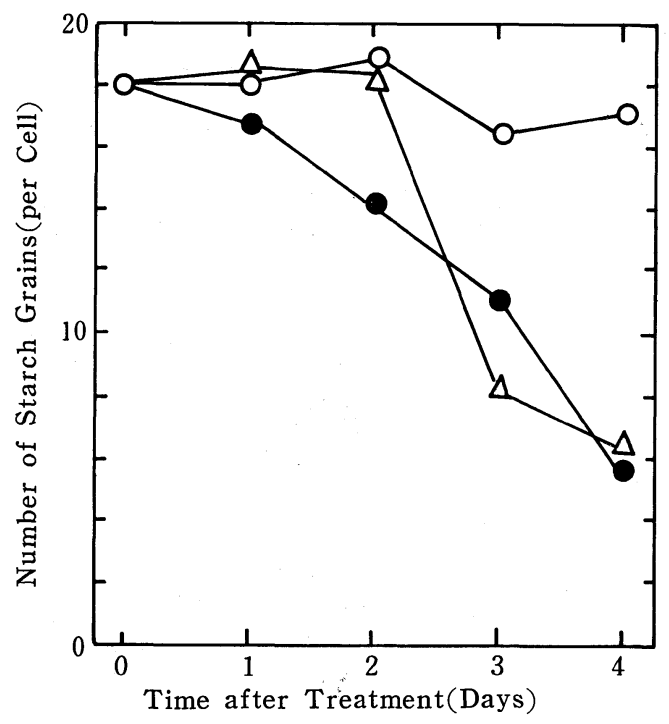

Fig. 1 Variation in the number of starch grains per cell. Open circle, closed circle and triangle indicate control, bacterium treatment and coronatine treatment, respectively.

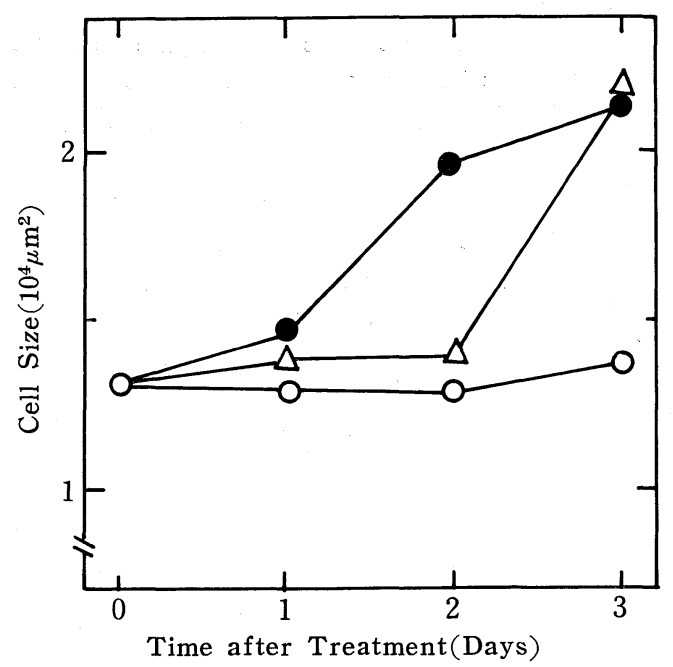

Fig. 2 Variation in cell size. Open circle, closed circle and triangle indicate control, bacterium treatment and coronatine treatment, respectively.

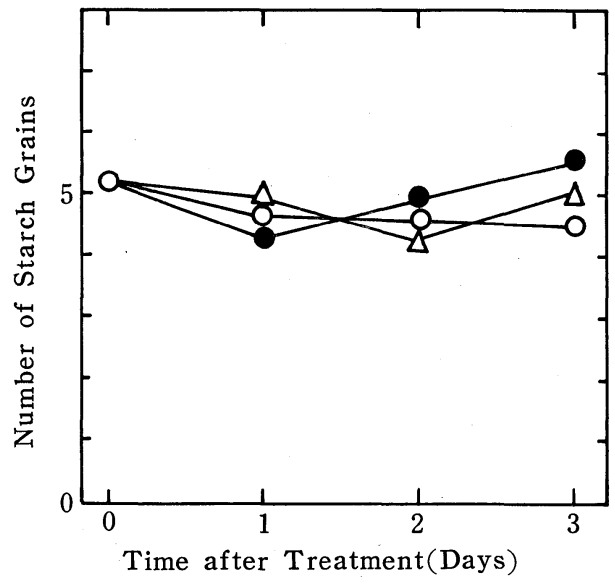

Fig. 3 Variation in the number of starch grains above $30 \mu \mathrm{m}$ in the major axis per cell. Open circle, closed circle and triangle indicate control, bacterium treatment and coronatine treatment, respectively.

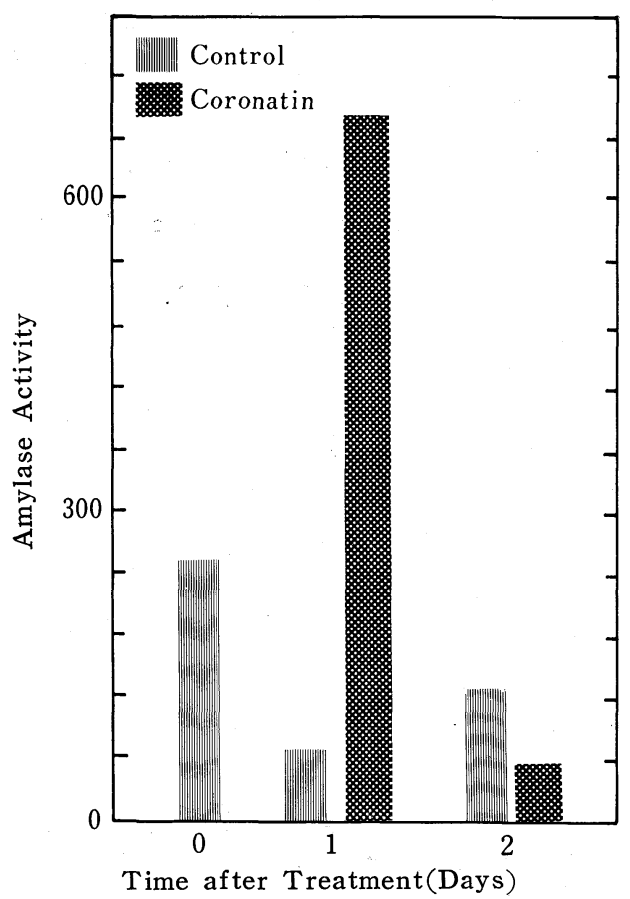

Fig. 4 Variation in amylase activity. The activity is expressed as the amount of reducing sugars produced $(\mu \mathrm{g} / \mathrm{ml})$.

non-treated discs within additional $24 \mathrm{hr}$. The levels of phosphorylase and debranching emzyme activities were little altered by coronatine treatment during the period tested (Figs. 5 and 6 ). This suggests that the decomposition of starch grains in the discs was mainly exerted by amylase. 


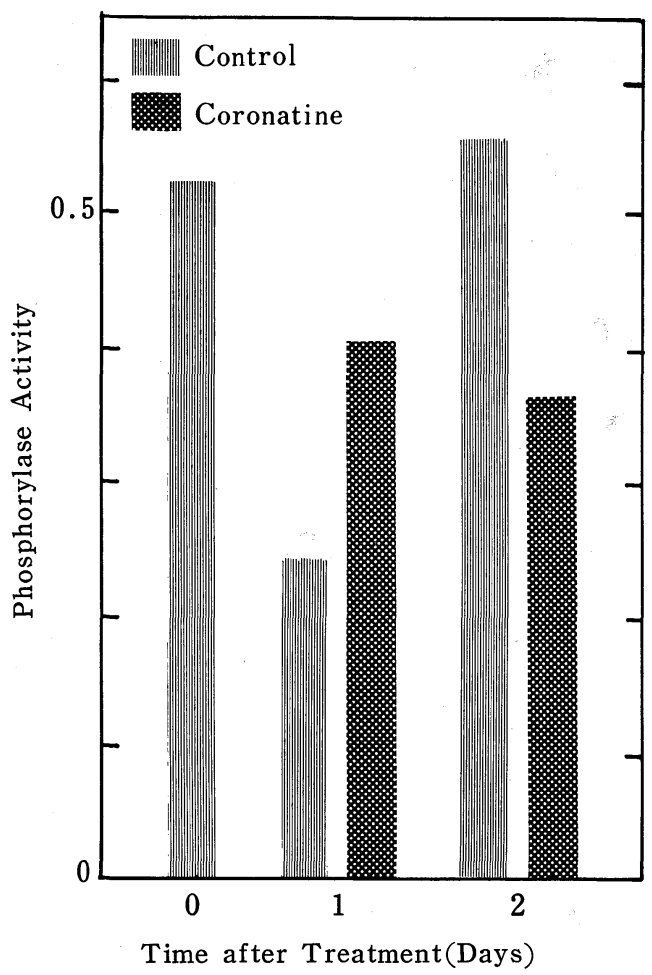

Fig. 5 Variation in phosphorylase activity. The activity is expressed as the amount of starch synthesized $(\mathrm{mg} / \mathrm{ml})$.

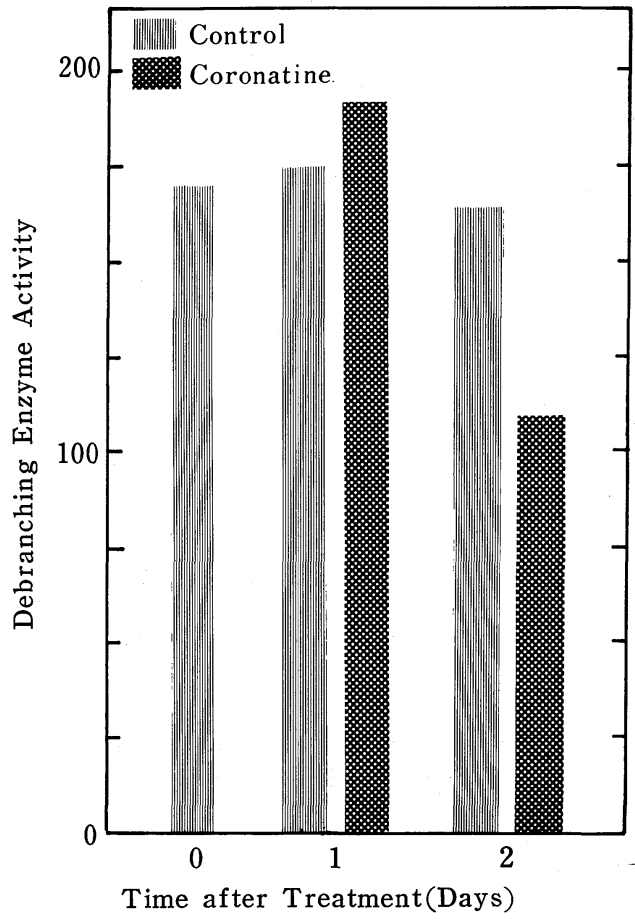

Fig. 6 Variation in debranching enzyme activity. The activity is expressed as the amount of reducing sugars produced $(\mu \mathrm{g} / \mathrm{ml})$.

\section{Inhibition of amylase activity}

Most of the amylase activities were inactivated by the presence of $0.1 \mathrm{mM} \mathrm{HgCl}_{2}$ (Fig. 7) or by heat treatment at $70 \mathrm{C}$ for $3 \mathrm{~min}$ (Fig. 8). This may suggest that the increase in amylase activity was mainly attributed to that in $\beta$-amylase.

\section{Variations in reducing sugars in the discs}

As shown in Fig. 9, the amount of reducing sugars in the discs treated with coronatine increased about twice as much as that in non-treated discs within 3 days. From all the results obtained, it is concluded that the decomposition of starch grains in the discs treated with coronatine may be exerted by the increased amylase activity and swelling of the cell may originate in the increase in osmotic pressure resulted from the starch decomposition, together with the loosening of cell wall.

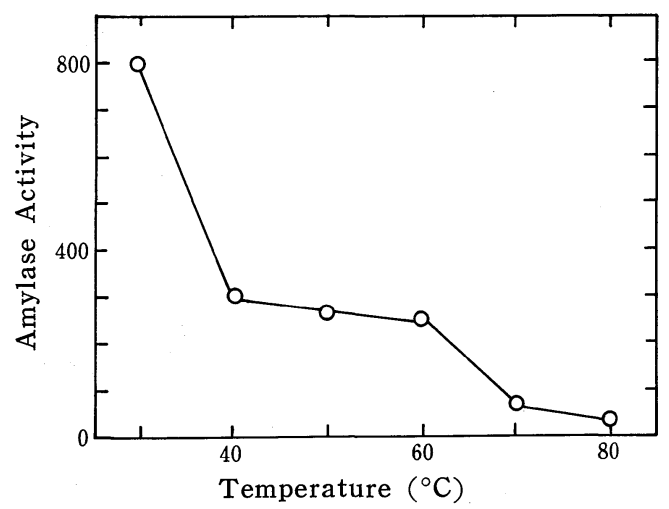

Fig. 8 Effect of heat treatment on the amylase activity. The activity is expressed as the amount of starch decomposed $(\mu \mathrm{g} / \mathrm{ml})$. 


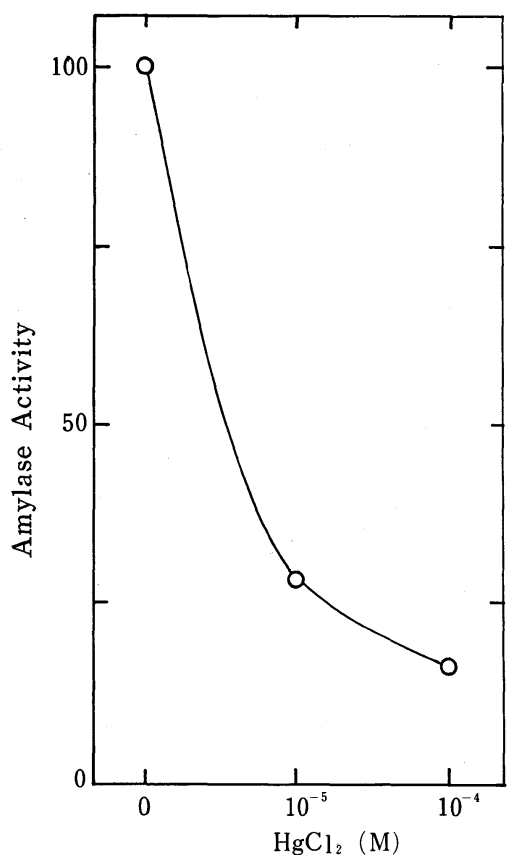

Fig. 7 Effect of $\mathrm{HgCl}_{2}$ on amylase activity in the discs treated with coronatine for 24 hr. The activity in the absence of $\mathrm{HgCl}_{2}$ is expressed as 100 .

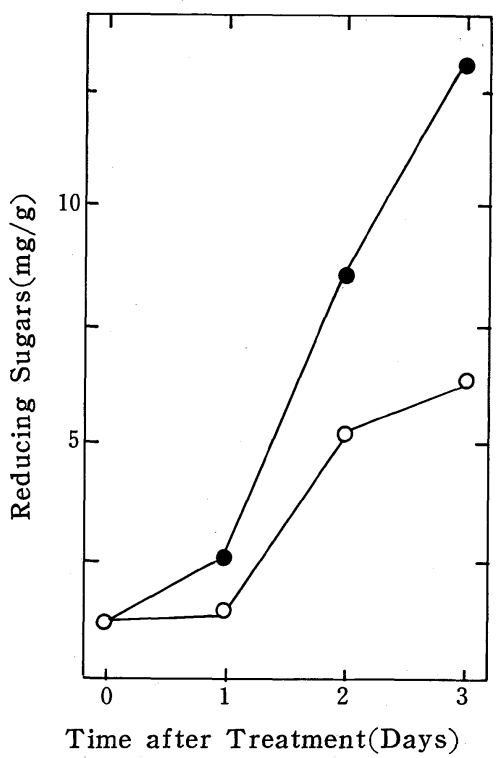

Fig. 9 Variation in the amount of reducing sugars in the discs. Open and closed circles indicate control and coronatine treatment, respectively.

\section{Discussion}

Sakai et al. reported that the plasticity of the cell wall in potato tuber was markedly increased by coronatine treatment, accompanied by increasing cell size ${ }^{7)}$. Up to the present, however, the mechanism has not been fully explained. In the present experiments, this swelling of the cell caused by coronatine can be partly elucidated in terms of the increase in osmotic pressure (Fig. 9) resulted from the decomposition of starch grains (Fig. 1), together with the loosening of cell wall, which lead to the active water absorption by the cell.

Nakamura ${ }^{5)}$ observed that small-sized starch grains were preferentially decomposed during the germination of barley seeds. Similar situation was found to be the case for the potato tuber treated with coronatine (Figs. 1 and 3). At the moment, however, we are uncertain that the same mechanism is operative in barley seeds and potato tuber.

In our experiments, amylase activity was revealed to increase considerably in the discs treated with coronatine in $24 \mathrm{hr}$ (Fig. 4). On the other hand, the activity was shown to decrease drastically within additional $24 \mathrm{hr}$ (Fig. 4). An explanation for this is that various quinones produced from phenolics by polyphenol oxidase inactivated most of amylase activities (cf. Table 1)., since polyphenol and ascorbate oxidases rose markedly in the discs treated with coronatine in 2 days, to the extent that the browning could no longer be prevented even by the homogenizing solution mentioned above (data are not detailed here). Even if such was the case, the decomposition of starch is considered to be mainly exerted by amylase, on the basis that the levels of phosphorylase and debranching enzyme were little altered by this 
treatment (Figs. 5 and 6).

Using the germinating barley seeds, Nakamura5) also demonstrated that $\alpha$-amylase can attack starch grains as well as soluble starch, but $\beta$-amylase can decompose starch grains only in the presence of $\alpha$-amylase. In our experiments, however, amylase activity was assayed using only soluble starch as a substrate. It remains therefore to be clarified whether the increased $\beta$-amylase activity is practically involved in the destruction of starch grains in potato tuber.

Many workers have reported that $\alpha$-amylases are newly synthesized in aleulon layer of germinating barley seeds by the action of gibberellin ${ }^{3,4,10)}$. On the other hand, Shinke and Mugibayashi reported the activation of latent $\beta$-amylase bound to cell wall during the germination of the same seeds ${ }^{8)}$. Coronatine is inferred to have gibberellin-like activity in terms of the induction of a hydrolase such as amylase. This compound is also assumed to have indole-3-acetic acid like activity as regards the loosening of the cell wall. Further investigations on such multiple activities of coronatine will therefore provide some useful clues for the elucidation of pathogenicity induced by this bacterium on Italian ryegrass.

We wish to express our thanks to Mr. K. Asama, Konsen Agricultural Experiment Station and $\mathrm{Mr}$. Y. Ishizaki, Tokyo University, for their kindly providing potato tubers and pullulan, respectively. We also thank Miss $\mathrm{K}$. Toyota for her technical assistance.

\section{Literature cited}

1. Fukui, S. (1969). Experimental Methods for Biological Chemistry, Tokyo University Press A-1 : 47 .

2. Ichihara, A., Shiraishi, K., Sato, H., Sakamura, S., Nishiyama, K., Sakai, R., Furusaki, A., and Matsumoto, T. (1977). J. Am. Chem. Soc. $99: 636$.

3. Jacobsen, J. V., Scandalios, J. G. and Varner, J. E. (1970). Plant Physiol. $45:$ 367-371.

4. Momotani, Y. and Kato, J. (1966). Plant \& Cell Physiol. 8 : 439-445.

5. Nakamura, M. (1978). Kagaku to Seibutsu $10: 626-640$.

6. Nishiyama, K., Sakai, R., Ezuka, A., Ichihara, A., Shiraishi, K., Ogasawara, M., Sato, H. and Sakamura, S. (1976). Ann. Phytopath. Soc. Japan $42: 613-614$.

7. Sakai, R., Nishiyama, K., Ichihara, A., Shiraishi, K., Sakamura, S. (1979). The relation between bacterial toxic action and plant growth regulator, in Recognition and Specification in Plant Host-Parasite Interactions ed. by Daly, J. M. and Uritani, I. Japan Scientific Societies Press and University Park Press, p. 165-178.

8. Shinke, R. and Mugibayachi, N. (1971). Agr. Biol. Chem. $35: 1381-1390$.

9. Térrago, J. F. and Nicolás, G. (1976). Plant Physiol. $58: 618-621$.

10. Varner, J. E. (1964). Plant Physiol. 64 : 413-415.

11. Yamazaki, Y. and Suzuki, Y. (1979). Plant \& Cell Physiol. $20: 553-562$.

和 文 摘 要

$$
\text { ジャガイモ塊茎切片中の測粉粒分解におよぼすコロナチンの影響 }
$$

酒井隆太郎・美濃羊輔・高地雅子・榎佐和子

イタリアンライグラスかさ枯れ病菌，Pseudomonas coronafaciens var. atropurpurea，によって生産 される菌体外毒素, コロナチンによるジャガイモ塊茎柔組織切片中の港粉粒分解におよぼす影響を調べた。 コロナチン処理により, 澱粉粒, とくに長径 $30 \mu \mathrm{m}$ 以下の比較的小型のあのが優先的に消失し, それに伴い 細胞も肥大した。本病原菌を接種した際にも，コロナチン処理の場合とほぼ同様の現象が観察された。コロ ナチン処理により，アミラーゼ活性はかなり増加したが, ホスホリラーゼおよび枝切酵素の活性はほとんど 変化しなかった。上記のととから, コロナチン処理によるジャガイモ塊茎柔組織切片中の細胞の肥大は, ア ミラーゼ活性の増大により生じた澱粉粒の分解にもとづく 細胞内浸透圧の増加と細胞壁の 可塑性の増大によ り引き起されるあのと考えられる。 